\title{
PENGARUH PENGGUNAAN TEPUNG BIJI KEMIRI DALAM PAKAN TERHADAP KINERJA REPRODUKSI BURUNG PUYUH (Coturnix coturnix japonica)
}

\author{
Effect of Use Candlenut Meal in Feed on Reproductive Performances of Quail \\ (Coturnix coturnix japonica) \\ Koen Malikah Afni Rahman ${ }^{1)}$, Sri Wahyuningsih ${ }^{2)}$ dan Eko Widodo ${ }^{3)}$ \\ ${ }^{1)}$ Mahasiswa Fakultas Peternakan, Universitas Brawijaya, Malang-65145, Indonesia \\ ${ }^{2)}$ Dosen Minat Produksi Ternak,Fakultas Peternakan, Universitas Brawijaya, Malang-65145, \\ Indonesia \\ ${ }^{3)}$ Dosen Minat Nutrisi dan Makanan Ternak, Fakultas Peternakan, Universitas Brawijaya, Malang-65145, \\ Indonesia \\ Email: malikahafni@gmail.com
}

\begin{abstract}
ABSTRAK
Penelitian ini bertujuan untuk mengetahui pengaruh penggunaan tepung biji kemiri dalam pakan terhadap kinerja reproduksi burung puyuh yang meliputi umur pertama bertelur, jarak antar bertelur, konsumsi pakan, HDP (Hen Day Production) dan jumlah folikel sel telur. Penelitian ini menggunakan 120ekor burung puyuh umur 30 hari). Pakan basal yang digunakan adalah pakan lengkap yang diproduksi oleh PT. Charoen Phokpand Indonesia (BP104). Metode yang digunakan pada penelitian ini yaitu metode percobaan dengan 4 perlakuan dan 6 ulangan.Bahan. Perlakuan yang diberikan antara lain: PO (pakan basal), P1 (pakan basal $+1 \%$ tepung biji kemiri), P2 (pakan basal+2\% tepung biji kemiri), dan P3 (pakan basal $+3 \%$ tepung biji kemiri). Data dianalisis menggunakan ANOVA dari RAL dan jika perlakuan memberikan pengaruh berbeda dilanjutkan dengan Duncan's Multiple Range Test. Hasil penelitian menunjukkan bahwa perlakuan tidak memberikan pengaruh nyata $(P>0,05)$ terhadap umur pertama bertelur dan jarak antar bertelur, dan memberikan pengaruh sangat nyata $(P<0,01)$ terhadap konsumsi pakan dan HDP (Hen Day Production) dan memberikan pengaruh nyata $(P<0,05)$ terhadap jumlah folikel sel telur. Kesimpulan dari penelitian ini adalah pemberian tepung biji kemiri sebanyak 3\% memberikan hasil yang terbaik dibandingkan dengan perlakuan yang lainnya.
\end{abstract}

Kata kunci: Burung puyuh, tepung biji kemiri, kinerja reproduksi

How to Cite :

Rahman, K. M. A., Wahyuningsih, S., \& Widodo, E. (2018). Pengaruh Penggunaan Tepung Biji Kemiri dalam Pakan Terhadap Kinerja Reproduksi Burung Puyuh (Coturnix coturnix japonica). Jurnal Nutrisi Ternak Tropis, 1 (1) 24-33
*Corresponding author:

Koen Malikah Afni Rahman

Email : malikahafni@gmail.com

Faculty of Animal Science, Brawijaya University,

Veteran Street, Malang, East Java, Indonesia. 65145 


\section{ABSTRACT}

The research was aimed to evaluate the effect of inclusion level of the candlenut meal in feed on reproductive performances of quail; age at first laying, HDP (Hen Day Production), feed intake, laying interval (hours) andnumber of ovum. This study used 120 layer quails of 30 days old. Basal feed used was complete feed produced by PT. Charoen Phokpand Indonesia (BP104). Treatments given were PO (basal feed without given of candlenut meal), $P 1$ (basal feed $+1 \%$ of candlenut meal, $P 2$ (basal feed $+2 \%$ of candlenut meal), P3 (basal feed $+3 \%$ of candlenut meal), 6 repeatition each. Data were performed to analysis of variance (ANOVA) of the Completely RandomizedDesign (CRD) and Duncan's Multiple Range Test (DMRT). The result showed that use of candlenut meal inquail feed up to the level of $3 \%$ did not significant influence $(P>0.05)$ on the values of age at first laying and laying interval (hours), but highly significant influence $(P<0.01)$ on the feed intake, HDP (Hen Day Production) and significantlyinfluenced $(P<0.05)$ on number of ovum. The use of candlenut meal up to the level $3 \%$ showed the best result.

Keywords: Candlenut meal, quail, reproductive

\section{PENDAHULUAN}

Jumlah penduduk Indonesia pada tahun 2000 mencapai 206 juta jiwa dan telah mencapai 241 juta jiwa pad tahun 2012 (BPS, 2012). Peningkatan pertumbuhan penduduk serta meningkatnya kesadaran masyarakat terhadap pentingnya gizi bagi kesehatan memaksa penyediaan pangan produk peternakan harus dihasilkan dengan cepat agar dapat mengimbangi kebutuhan masyarakat. Disamping kebutuhan masyarakat terhadap protein hewani yang semakin tinggi, hal ini juga dapat dilihat adanya ketidakseimbangan antara permintaan daging yang meningkat yaitu sekitar 6-8\% tiap tahunnya dengan persediaan daging yang ada serta pertambahan populasi ternak yang tersedia belum mencukupi kebutuhan. Pemerintah harus meningkatkan pembangunan subsektor pengembangan keanekaragaman ternak sumber protein hewani. Selain dari daging ayam, sapi, domba atau kambing, ternak lain yang berpotensi sebagai penghasil protein hewani adalah burung puyuh.

Kinerja reproduksi burung puyuh dapat ditingkatkan dengan cara pemberian pakan yang sesuai. Faktor pakan merupakan hal yang sangat penting untuk diperhatikan, terutama zat-zat yang terkandung dalam bahan pakan yang diberikan karena dapat mempengaruhi keberhasilan dalam produksi telur. Pemberian pakan yang tepat dapat meningkatkan kemampuan burung puyuh untuk memproduksi telur yang tinggi. Salah satu pakan alternatif yang dapat dimanfaatkan sebagai pakan puyuh yaitu tepung biji kemiri.

Biji kemiri mengandung asam lemak yang tidak dapat disintesis dalam tubuh sehingga harus tersedia dalam pakan (esensial) yang terdiri dari: apha-linolenic acid (ALA), linoleic acid (LA) dan oleic acid (OC) (Ketaren, 2012). Biji kemiri mengandung zat aktif yaitu saponin dan flavonoid.Kandungan flavonoid dalam biji kemiri dapat berfungsi sebagai antioksidan yang dapat menstabilkan radikal bebas, sedangkan saponin dapat berfungsi sebagai antibakteri. Berdasarkan uraian tersebut maka penulis melakukan penelitian tentang pengaruh penggunaan tepung biji kemiri dalam pakan terhadap kinerja reproduksi burung puyuh yang meliputi umur pertama bertelur, jarak antar bertelur, konsumsi pakan, Hen Day Production (HDP) dan jumlah folikel sel telur. 


\section{MATERI DAN METODE}

1. Burung Puyuh

Burung puyuh siap bertelur (umur 30 hari) sebanyak 120 ekor dengan jenis (Coturnix coturnix japonica).

2. Pakan

Pakan yang digunakan sebagai pakan basal adalah pakan jadi yang diproduksi oleh PT. Charoen
Pokphand Indonesia (BP104) dalam bentuk butiran (crumble). Pakan perlakuan yang digunakan tersusun berdasarkan kebutuhan zat makanan untuk puyuh periode layer.

3. Tepung Biji Kemiri (TBK)

Berikut merupakan prosedur pembuatan TBK.

Gambar 1. Prosedur Pembuatan TBK

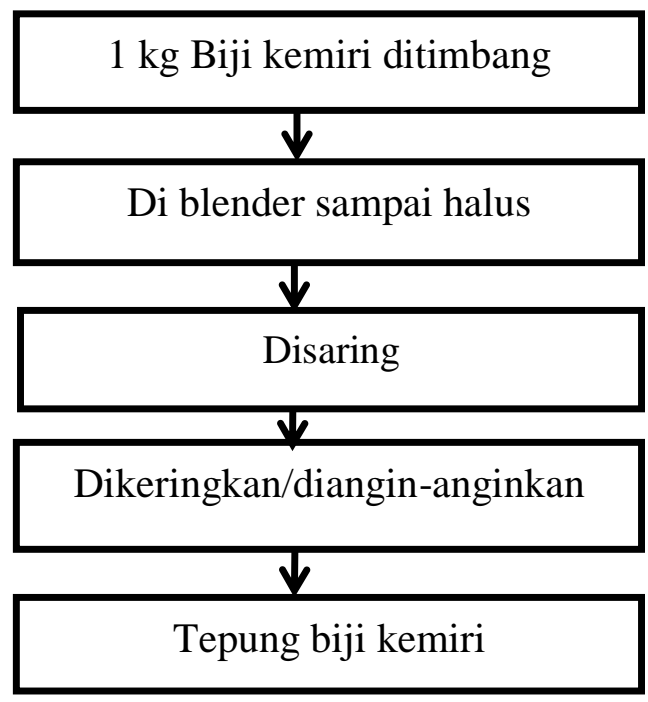

Tabel 1. Kandungan zat makanan pakan basal dan tepung biji kemiri (TBK)

\begin{tabular}{llcl}
\hline Zat makanan & Pakan basal $(\%)^{*}$ & Pakan basal $(\%)^{* *}$ & TBK $(\%)^{* *}$ \\
\hline Kadar air & $13($ maks) & 10,42 & - \\
\hline Bahan Kering & - & 89,76 & 99,80 \\
Protein & $20,00-22,00$ & 22,23 & 6,21 \\
Lemak & $3,50($ min) & 6,37 & 64,92 \\
Serat & $5,00($ maks) & 4,66 & 4,61 \\
Abu & $12,00(\mathrm{~min})$ & 11,78 & 3,20 \\
Kalsium & $3,00($ min $)$ & - & - \\
Phospor & $0,60($ min) & - & - \\
Antibiotik & Zinc Bacitracin & - & - \\
$G E($ Kkal/kg) & - & 4142,95 & 7690,57 \\
EM $(\mathrm{Kkal} / \mathrm{kg})^{* * *}$ & & 2900,06 & 5358,40
\end{tabular}

Sumber: $\quad(*)$ Label Pakan puyuh petelur dewasa produksi PT. Charoen Pokphand Indonesia.

(**) Hasil analisis Laboratorium Nutrisi dan Makanan Ternak Fakultas Peternakan Universitas Brawijaya Malang.

(***)Hasil perhitungan 70\% dikalikan dengan GE (Kkal/kg)

4. Kandang dan peralatan

Kandang sistem battery yang terbagi menjadi 24 kotak dengan ukuran kotak 30 x 20 x $20 \mathrm{~cm}$. Kandang terbuat dari bambu, dilengkapi dengan lampu penerangan serta tempat pakan dan tempat minum yang terbuat dari plastik dan pipa paralon. 


\section{Metode:}

Metode Penelitian yang digunakan adalah metode percobaan dengan Rancangan Acak Lengkap (RAL) pola searah dengan 4 perlakuan dan 6 kali ulangan, terdapat 24 unit percobaan, setiap unit diisi 5 ekor burung puyuh, perlakuan yang diberikan terdiri dari:

P0 :Pakan Basal (kontrol)

P1: Pakan Basal+Tepung Biji

Kemiri(TBK) $1 \%$

P2: Pakan Basal+Tepung Biji Kemiri (TBK) $2 \%$

P3 : Pakan Basal+Tepung Biji Kemiri(TBK) $3 \%$

\section{Variabel penelitian:}

Variabel yang diamati pada penelitian adalah kinerja reproduksi burung puyuh, yang meliputi: a. Umur pertama bertelur

Umur pertama bertelur dihitung dengan mencatat pada umur (hari) keberapa burung puyuh pada tiap kotak perlakuan untuk pertama kalinya bertelur pada masing - masing perlakuan.

b. Jarak antar bertelur (jam)

Jarak antar bertelur dihitung dengan mencatat jam berapa dalam setiap kotak perlakuan burung puyuh yang terlebih dahulu bertelur dalam per unit percobaan sampai bertelur berikutnya dalam waktu 24 jam/sehari.

c. Konsumsi pakan (g/ekor/hari)

Konsumsi pakan dihitung dengan dengan cara mengurangi jumlah pakan yang diberikan dengan sisa pakan (g/ekor/hari).

Konsumsi pakan $=\sum$ pakan yang diberikan

(1 minggu) - $\sum$ pakan sisa (1 minggu) / 7

d. HDP (Hen Day Production)

Dihitung dengan cara jumlah telur yang dihasilkan hari ini dibagi dengan populasi burung puyuh hari ini (\%) Srisukmaati dan Syahruddin (2012).

$$
\mathrm{HDP}=\frac{\text { Jumlah telur hari ini }}{\text { Jumlah puyuh yang ada hari ini }} \times 100 \%
$$

e. Jumlah folikel sel telur

Pengambilan data jumlah folikel sel telur dilakukan pada hari terakhir penelitian (umur 82 hari) setelah perlakuan, kemudian menimbang berat badan dan membedah burung puyuh mengamati struktur makroskopis folikel telur burung puyuh dan dihitung jumlah folikel sel telur burung puyuh.

Data hasil data pengamatan dianalisis dengan menggunakan ANOVA dari RAL, apabila ada perbedaan diantara perlakuan maka dilanjutkan Uji Jarak berganda Duncan (Steel dan Torrie, 1992). 


\section{HASIL DAN PEMBAHASAN}

Tabel 2.Pengaruh penambahan tepung biji kemiri dalam pakan terhadap kinerja reproduksi burung puyuh.

\begin{tabular}{|c|c|c|c|c|c|}
\hline \multirow{2}{*}{$\begin{array}{l}\text { Variabel yang } \\
\text { diamati }\end{array}$} & \multicolumn{4}{|c|}{ Perlakuan } & \multirow{2}{*}{ Signifikasi } \\
\hline & P0 & P1 & P2 & P3 & \\
\hline $\begin{array}{l}\text { Umur } \\
\text { pertama } \\
\text { bertelur(hari) }\end{array}$ & $44 \pm 0,89$ & $45,83 \pm 3,18$ & $46,16 \pm 1,83$ & $44,66 \pm 1,96$ & Ns \\
\hline $\begin{array}{l}\text { Jarakantar } \\
\text { bertelur(jam) }\end{array}$ & $24,14 \pm 0,26$ & $24,15 \pm 0,24$ & $24,46 \pm 0,18$ & $23,94 \pm 0,17$ & Ns \\
\hline $\begin{array}{l}\text { Konsumsi } \\
\text { pakan } \\
\text { (g/ekor/hari) }\end{array}$ & $24,81 \pm 0,29^{\mathrm{a}}$ & $24,9 \pm 0,10^{\mathrm{ab}}$ & $24,62 \pm 0,07^{\mathrm{a}}$ & $25,96 \pm 0,08^{b}$ & $* *$ \\
\hline $\operatorname{HDP}(\%)$ & $78,09 \pm 3,90^{\mathrm{a}}$ & $79,52 \pm 4,92^{\mathrm{a}}$ & $79,99 \pm 8,47^{\mathrm{a}}$ & $90,59 \pm 3,26^{b}$ & $* *$ \\
\hline $\begin{array}{l}\text { Jumlah } \\
\text { folikel sel } \\
\text { telur(buah) }\end{array}$ & $54,83 \pm 15,88^{a}$ & $46,66 \pm 21,57^{\mathrm{a}}$ & $49,5 \pm 12,44^{\mathrm{a}}$ & $74,66 \pm 10,76^{\mathrm{b}}$ & $*$ \\
\hline
\end{tabular}

Keterangan: (*) Superskrip yang berbeda pada baris yang sama menunjukkan perbedaan yang nyata $(\mathrm{P}<0,05)$.

(**) Superskrip yang berbeda pada baris yang sama menunjukkan perbedaan yang sangat nyata $(\mathrm{P}<0,01)$.

\section{Pengaruh Perlakuan terhadap Umur Pertama Bertelur}

Hasil pengamatan penelitian pada Tabel 2. menunjukkan bahwa umur pertama bertelur dari nilai tertinggi hingga terendah berturut-turut yaitu $\mathrm{P} 2$ $(46,16 \pm 1,83), \quad$ P1 $\quad(45,83 \pm 3,18), \quad$ P3 $(44,66 \pm 1,96)$ dan P0 $(44 \pm 0,89)$ hari. Hal tersebut menunjukkan bahwa pengaruh penggunaan tepung biji kemiri dalam pakan burung puyuh tidak memberikan pengaruh yang nyata $(\mathrm{P}>0,05)$ terhadap umur pertama bertelur.

Secara numerik umur pertama bertelur yang tercepat didapatkan pada perlakuan P0 dengan rataan umur pertama bertelur 44 hari dengan tanpa penggunaan TBK. Hal ini dikarenakan masa adaptasi untuk pemberian perlakuan hanya 7 hari sehingga pakan yang diberikan dengan cara pembatasan dan diberikan satu kali sehari pada sore hari tidak merangsang organ-organ reproduksi dalam proses pembentukan telur. Produksi telur sangat ditentukan oleh konsumsi pakan, kandungan protein pakan dan faktor hormonal dalam proses pembentukan telur, selain itu faktor kesehatan, tata laksana dan makanan juga mempengaruhi umur pertama bertelur (Triyanto, 2007). Puyuh akan mencapai dewasa kelamin pada umur 6 minggu dan akan segera memulai periode bertelur (Cowell, 1997). Wiradimadja, dkk (2006) menyatakan untuk mendukung produksi telur yang tinggi, membutuhkan perkembangan organ-organ reproduksi yang baik (organorgan dalam yang berfungsi langsung mupun tak langsung dalam membentuk dan membuat telur) dan tinggi rendahnya produksi telur pada burung puyuh jugadipengaruhi faktor antara lain kenyamanan baik dalam maupun luar kandang, menjaga kesehatanburung puyuh, tatalaksana rutin pemeliharan, pakan dan pemberinnya.Daulay, dkk (2007) menambahkan bahwa umur pertama bertelur pada puyuh lebih lama disebabkan oleh laju pertumbuhan yang terhambat karena menurunnya sintesis protein akibat cekaman panas. 
Dewasa kelamin pada burung puyuh betina ditandai dengan pertama kali bertelur, burung puyuh pertama bertelur berumur 35-72 hari dengan rataan umur 41 hari Wiradimaja, dkk (2006). Menurut Varghese (2007) puyuh mulai bertelur pada umur 35 hari pada kondisi yang baik. Dewasa tubuh pada puyuh terjadi sebelum dewasa kelamin, tercapainya dewasa tubuh ini dipengaruhi oleh kualitas pakan. Pakan yang mengandung protein tinggi akanmampu mempercepat dewasa tubuh. Fungsi protein sebagai zat pembangun jaringan tubuh secara langsung akanmempercepat pertumbuhan dan perkembangan organ tubuh terutama organ reproduksinya. Setelah semua organ reproduksi mencapai pertumbuhan maksimal, maka saat itulah dikatakan ternak telah mengalami dewasa tubuh, lalu menuju dewasa kelamin. Dewasa kelamin ini tercapai setelah kondisi organ reproduksi telah siap secara fisiologisnya, sudah mampu memproduksi hormon reproduksi dan telah mampu memproduksi sel telur sebagai bakal telur.

\section{Pengaruh Perlakuan terhadap Jarak Antar Bertelur}

Hasil pengamatan penelitian pada Tabel 2. Menunjukkan bahwa rataan jarak antarbertelur dari nilai tertinggi hingga terendah berturut-turut yaitu P2 $(24,46 \pm 0,18), \quad \mathrm{P} 1 \quad(24,15 \pm 0,24), \quad \mathrm{P} 0$ $(24,14 \pm 0,26)$ dan P3 $(23,94 \pm 0,17)$ jam. Hal tersebut menunjukkan bahwa pengaruh pemberian tepung biji kemiri dalam pakan burung puyuh tidak memberikan pengaruh yang nyata $(\mathrm{P}>0,05)$ terhadap jarak antar bertelur.

Jarak waktu yang dibutuhkan seekor burung puyuh betina untuk menghasilkan satu butir telur dengan telur yang berikutnya dihitung dalam jam (jarak antar bertelur). Secara numerik jarak antar bertelur (jam) yang tercepat didapatkan pada perlakuan P3 dengan rata - rata jarak antar bertelur 23,94 jam dengan penggunaan TBK sebanyak 3\%. Jarak antar bertelur (jam) pada penelitian ini menunjukkan tidak berbeda nyata dengan kisaran 23,94 sampai 24,46 jam. Hal ini disebabkan adanya kandungan saponin yang menghambat penyerapan zat makanan, sehingga didalam organ reproduksi kurang optimal dalam proses pembentukan telur. Tepung biji kemiri mengandung zat aktif saponin, flavonoid, dan polifenol yang dapat berfungsi sebagai anti mikroba di dalam organ reproduksi, tetapi mungkin efek saponin lebih dominan. Menurut Sinurat, dkk (2003) menyatakan bahwa salah satu mekanisme kerja bioaktif dalam meningkatkan kinerja reproduksi pada unggas adalah dengan cara menghambat pertumbuhan mikroorganisme patogen didalam saluran pencernaan, atau dapat juga dikatakan sebagai anti bakteri. Rataan jarak antar bertelur pada penelitian ini masih dalam kisaran hasil penelitian Pond and Wilson (2000) yaitu berkisar antara 23-26 jam. Bila jarak antar bertelur lewat dari 24 jam, maka telur akan dikeluarkan pada hari berikutnya.

Menurut Achmanu dan Muharlien, (2012)perjalanan sebutir telur dalam alat reproduksi betina membutuhkan waktu 25 jam. Nuryadi (2000) menyatakan bahwa perjalanan telur sepanjang oviduct pada semua unggas adalah serupa. Perkembangan telur memerlukan waktu selama kira-kira 15 menit dalam infundibulum. Magnum mempunyai laju pergerakan $2 \mathrm{~mm}$ per menit, sehingga total memerlukan waktu kira-kira 2 atau 3 jam. Dalam isthmus memerlukan waktu 60-90 menit dan kira-kira 20 jam dalam uterus, sehingga total perjalanan telur dalam oviduk adalah kira-kira 26 jam, sedang dalam vagina hanya beberapa detik saja.

\section{Pengaruh Perlakuan terhadap Konsumsi Pakan}

Hasil pengamatan penelitian pada Tabel 2. Menunjukkan bahwa rataan konsumsi pakan dari nilai tertinggi hingga terendah berturut-turut yaitu P3 $(25,96 \pm 0,08), \quad$ P1 $\quad(24,9 \pm 0,10), \quad$ P0 $(24,81 \pm 0,29) \quad$ dan $\quad$ P2 $(24,62 \pm 0,07)$ 
g/ekor/hari. Hal tersebut menunjukkan bahwa pengaruh pemberian tepung biji kemiri dalam pakan burung puyuh memberikan pengaruh yang sangat nyata $(\mathrm{P}<0,01)$ terhadap konsusmi pakan.

Secara numerik konsumsi pakan yang tertinggi didapatkan pada perlakuan P3 dengan rataan konsumsi pakan 25,96 g/ekor/hari dengan penggunaan TBK sebanyak 3\%. Hal ini disebabkan karena pengaruh kandungan zat aktif biji kemiri yaitu polifenol. Kandungan polifenol dalam biji kemiri dapat berfungsi sebagai antioksidan dan anti bakteri yang dapat menstabilkan radikal bebas. Weiss and Hogan (2007) menyatakan bahwa penggunaan bahan yang memiliki kandungan antioksidan pada ternak dapat mengurangi efek radikal bebas seperti meningkatkan konsumsi pakan. Hal ini dikarenakan radikal bebas dapat menyebabkan oxidative stress pada ternak sehingga dapat menurunkan konsumsi pakan. Oxidative stress adalah kondisi tidak seimbangnya jumlah radikal bebas dan antioksidan yang ada di dalam tubuh dimana jumlah radikal bebas lebih tinggi daripada jumlah antioksidan sehingga dapat memicu terjadinya kerusakan sel dan menurunkan daya tahan tubuh (Nurliyana et al, 2010).

Kasiyati, dkk (2010) berpendapat unggas mengkonsumsi pakan untuk memenuhi kebutuhan energi metabolis sehingga kadar energi metabolis yang terkandung di dalam pakan akan mempengaruhi konsumsi pakan. Ditambahkan oleh Tillman, et al (1991) bahwapakan yang memiliki kandungan energi metabolis tinggi akan menyediakan protein yang cenderung rendah dalam tubuh unggas diakibatkan karena rendahnya jumlah pakan yang dikonsumsi. Sebaliknya, apabila energi metabolis pakan rendah maka unggas akan mengkonsumsi pakan untuk mendapatkan energi lebih banyak yang berakibat pada konsumsi protein yang berlebihan.

Menurut Ketaren (2012)Tepung Biji Kemiri (TBK) sebagai feed supplement (pakan tambahan) dengan kandungan Gross Energy dan Lemak kasar yang lebih tinggi dari pakan basal, (Gross Energy pada TBK sebesar 7690,57 Kkal/kg), sedangkan kandungan Gross Energy pada pakan basal sebesar 4142,95 Kkal/kg. Begitu juga dengan kandungan Lemak kasar pada TBK sbesar 64,92\% sedangkan kandungan Lemak kasar pada pakan basal sbesar 6,37\%. Tepung Biji Kemiri (TBK) ini mengandung asam lemak tak jenuh yaitu apha-linolenic acd (ALA) atau asam linolenat, linoleic acid (LA) atau asam linoleat, dan oleic acid (OC) atau asam oleat.

\section{Pengaruh Perlakuan terhadap HDP (Hen Day Production)}

Hasil pengamatan penelitian pada Tabel 2. Menunjukkan bahwa rataan HDP (Hen Day Production) dari nilai tertinggi hingga terendah berturut-turut yaitu P3 $(90,59 \pm 3,26), \quad$ P2 $\quad(79,99 \pm 8,47), \quad$ P1 $(79,52 \pm 4,92)$ dan P0 $(78,09 \pm 3,90) \%$. Hal tersebut menunjukkan bahwa pengaruh pemberian tepung biji kemiri dalam pakan burung puyuh memberikan pengaruh sangat nyata $(\mathrm{P}<0,01)$ terhadap HDP (HenDay Production).

Secara numerik persentase HDP yang tertinggi didapatkan pada perlakuan P3 dengan rata - rata HDP 90,59\%, dengan penggunaan TBK sebanyak $3 \%$. Hal ini dapat disebabkan karena pengaruh konsumsi pakan dan kandungan zat makanan dalam pakan dan tepung biji kemiri (TBK). Faktor utama yang mempengaruhi produksi telur adalah kandungan zat makanan dalam pakan (Djulardi, 2006). Idris (2002) menyatakan bahwa tingkat konsumsi protein dan energi secara fisiologis akan berpengaruh terhadap HDP yang dihasilkan. Widyastuti, dkk (2014) menyatakan bahwa produksi ternak dipengaruhi oleh jumlah pakan yang dikonsumsi, semakin rendah konsumsi pakan maka produksi telur juga akan menurun begitu juga sebaliknya. Ditambahkan oleh Bakrie, dkk (2011)bahwa produksi telur dipengaruhi 
oleh konsumsi energi dan protein oleh ternak. Djulardi (2006) menyatakan bahwa faktor utama yang mempengaruhi produksi telur adalah jumlah pakan yang dikonsumsi dan kandungan zat makanan dalam pakan. Peningkatan kandungan protein dalam pakan dapat meningkatkan bobot telur dan produksi telur. Darmawan, Wiryawan dan Sumiati (2013) menyatakan bahwa penggunaan asam lemak omega 3 dan omega 6 meningkatkan produksi telur, menghasilkan performa produksi paling baik dan tidak menurunkan kualitas telur.

Zahra, dkk (2012) menyatakan bahwa produksi telur dipengaruhi oleh strain, umur pertama bertelur, konsumsi pakan dan kandungan protein pakan, sedangkan menurut Setyawan (2006) ditentukan oleh produksi ovum yang dipengaruhi jumlah pakan yang dikonsumsi dan proses hormonal. Menurut Mirnawati, dkk (1997) pakan yang dikonsumsi oleh ternak digunakan untuk hidup pokok dan kemudian untuk pertumbuhan dilanjutkan untuk produksi dan sebagian dikeluarkan sebagai sisa metabolisme tubuh. Kemampuan berproduksi mulai awal produksi akan terus mengalami kenaikan secara drastis hingga mencapai puncak produksi (top production $98,5 \%$ ) pada umur 4 - 5 bulan dan perlahan-lahan menurun hingga $70 \%$ pada umur 9 bulan

\section{Pengaruh Perlakuan terhadap Jumlah Folikel Sel Telur}

Data hasil penelitian pada Tabel 2 . Menunjukkan bahwa raatan jumlah folikel sel telur dari nilai tertinggi hingga terendah berturut-turut yaitu P3 $(74,66 \pm 10,76), \quad$ P0 $\quad(54.83 \pm 15,88), \quad$ P2 $(49.5 \pm 12,44)$ dan P1 $(46.66 \pm 21,57)$ buah. Hal tersebut menunjukkan bahwa pengaruh pemberian tepung biji kemiri dalam pakan burung puyuh memberikan pengaruh nyata $(\mathrm{P}<0,05)$ terhadap jumlah folikel sel telur.

Secara numerik jumlah folikel sel telur yang tertinggi didapatkan pada perlakuan P3 dengan rata - rata jumlah sel telur 74,66buah dengan penggunaan TBK sebanyak 3\%.Hal ini disebabkankarena tepung biji kemiri (TBK) yang digunakan dalam pakan burung puyuh mengandung asam lemak esensial yaitu asam linoleat, asam linolenat, dan asam oleat yang dapat merangsang organ reproduksi untuk mensekresikan hormon LH dan FSH dalam pembentukan folikel sel telur. Menurut Setianto (2005) asam linoleat akan mengontrol protein dan lipida yang diperlukan untuk perkembangan folikel dan secara langsung mengontrol ukuran telur, sehingga bentuk telur menjadi besar.

Lesson dan Summer (1991) produksi telur juga dipengaruhi oleh asam linoleat dan metionin. Hal tersebut didukung oleh pendapat March dan McMillan (1990) yang menyatakan bahwa asam lemak linoleat mempengaruhi produksitelur karena diperlukan sebagai penyusun komplek lipoprotein kemudian disintesis di hati, distimulasi hormon estrogen dan ditransfer untuk pembentukkan folikel dan secara langsung mengontrol bobot telur yang akan dihasilkan.

Asam lemak esensial merupakan salah satu zat makanan yang penting untuk unggas karena asam lemak ini berhubungan dengan integritas pada struktur membran mitokondria dan terdapat dalam konsentrasi tinggi pada organ-organ reproduksi (Tranggono, 2001). Peningkatan produksi dan reproduksi ayam lokal sangat tergantung dari pakan yang diberikan terutama asam lemak essensial, asam lemak berikatan rangkap tinggi bertanggung jawab terhadap permeabilitas dan aktivasi membran untuk mengikat enzim dan mengatur proliferasi sel, komponen asam empedu dan penyusun hormon steroid termasuk didalamnya hormon reproduksi. Manfaat lainnya adalah bahwa asam lemak omega-3 akan dimetabolisme menghasilkan aikosanoid seperti prostaglandin (Wahju, 2004). Menurut Indi dan Zulkarnain (2012) asam lemak omega-3 dalam minyak dapat merangsang produksi hormon-hormon yang berfungsi 
sebagai anti agregator, yaitu anti penggumpalan darah pada arteri, dan hormon-hormon tersebut diperlukan bagi perkembangan folikel.

\section{KESIMPULAN}

Penggunaan Tepung Biji Kemiri (TBK) dalam pakan hingga level 3\% tidak meningkatkan umur pertama bertelur dan jarak antar bertelur (jam), tetapi mampu meningkatkan konsumsi pakan, HDP (Hen Day Production) dan jumlah folikel sel telur. Pemberian tepung biji kemiri sebanyak 3\% dalam pakan memberikan kualitas yang terbaik. Penelitian lebih lanjut disarankan dengan menggunakan metode pemanasan biji kemiri untuk menghilangkan kandungan saponin, dalam meningkatkan kinerja reproduksi burung puyuh.

\section{DAFTAR PUSTAKA}

Darmawan, A., Wiryawan, K. G., \& Sumiati, S. (2013). Egg production $\&$ quality of magelang duck fed diets containing different ratio of omega 3: omega $6 \&$ organic Zn. Media Peternakan, 36(3), 197-202. https://doi.org/10.5398/medpet.2013. 36.3.197

Daulay, A. ., Bahri, I., \& Saputra, K. (2007). Pemanfaatan tepung buah mengkudu (Morinda citrifolia) dalam rasum terhadap performance burung puyuh (Coturnix coturnix japonica) umur 0-42 hari. Jurnal Agribisnis Peternakan, 3(1).

Djulardi, A., Muis, H., \& Latif, A. S. (2006). Nutrisi aneka ternak \& satwa. Padang: Fakultas Peternakan Universitas Andalas.

Idris, S. (2002). Ilmu \& teknologi pengawetan telur. Malang: Universitas Brawijaya Malang.
Ketaren, S. (2012). Minyak \& Lemak Pangan. Jakarta: Universitas Indonesia Press.

Lesson, S., \& Summer, J. D. (1991). Commercial poultry nutrition. Canada: University Books.

Mirnawati, A., Sulisna, L., \& Imsya, A. (1997). Pemberian ransum berdasarkan efisiensi penggunaan protein terhadap performans ayam ras petelur. Jurnal Peternakan \& Lingkungan, 52, 251-266.

Nurliyana, R., Zahir, S. I., Suleiman, M. K., Aisyah, R. M., \& Rahim, K. K. (2010). Antioxidant study of pulps \& peels of dragon fruit: a comparative study. International Food Research Journal, 17(2), 367-375.

Nuryadi. (2000). Dasar - dasar reproduksi ternak. Malang: Universitas Brawijaya Press.

Pond, K., \& Wilson, V. (2000). Introduction to animal science. United States of America: Jhon Wiley \& Son INC.

Setyawan, M. (2006). Menyinari layer, menangguk telur.

Sinurat, S. ., Purwadaria, T., Togatorop, M. H., \& Pasaribu, T. (2003). Pemanfaatan bioaktif tanaman sebagai feed additive pada ternak unggas: pengaruh pemberian gel lidah buaya atau ekstraknya dalam ransum terhadap penampilan produksi ayam pedaging. Jurnal Ilmu Ternak \& Veteriner, 8(3), 139-145.

Srisukmawati, \& Syahruddin. (2012). Pemanfaatan tepung keong mas sebagai subtitusi tepung ikan dalam ransum terhadap performa \& produksi telur puyuh. Gorontalo: Universitas Gorontalo. 
Steel, G. D., \& Torrie, J. H. (n.d.). Prinsip \& prosedur statistika, suatu pendekatan biometri. Jakarta: PT. Gamedia.

Tillman, A. ., Hari, H., Soedomo, R., Soeharto, P., \& Sukato, I. (1991). Ilmu makanan ternak dasar. Yogyakarta: Universitas Gajah Mada Press.

Tranggono. (2001). Lipid dalam Perspektif ilmu \& teknologi Pangan. Yogyakarta: Pidato Pengukuhan Guru Besar Fakultas Teknologi Pertanian UGM.
Triyanto. (2007). Performan produksi burung puyuh (Coturnix coturnix japonica) periode produksi umur 613 minggu pada lama pencahayaan yang berbeda. Jurnal Agribisnis Peternakan, 3(3), 45-49.

Varghese, S. K. (2007). The japanese quail. Canada: Peather Fancier Newspaper.

Wahju, J. (2004). Ilmu nutrisi unggas. Yogyakarta: Gadjah Mada University Press. 